\title{
Perichōrēsis and the South African ideal
}

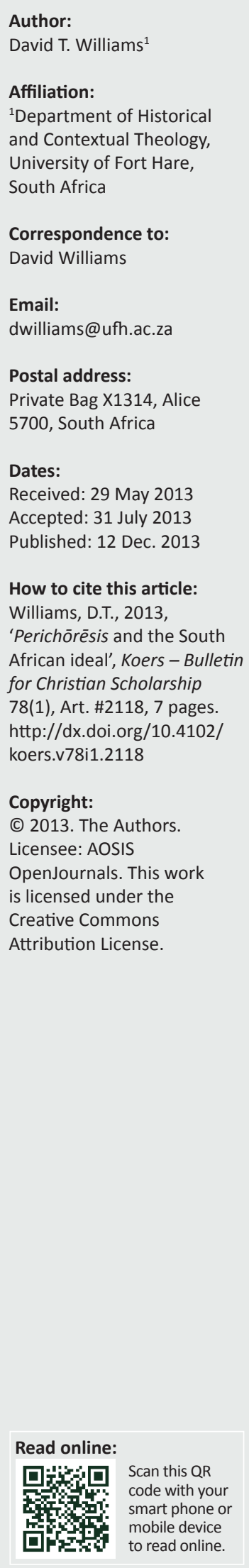

The continuing fulfilment of the South African dream of a 'rainbow nation' really needs to be based on a valid model; this can be provided by the biblical representation of the 'image of the Trinity'. In this regard, it is significant that the developed understanding of the Trinity includes the dynamic interaction of the Persons, known as perichōrēsis. If this serves as a model, it reflects the distinction between groups in society, but also harmony in society, and the full potential of each group. It then involves mutual sharing in society, and must be seen as dynamic, so that the country is able to continue to develop, not resting on past achievements. For Christians, part of the enactment of this model can be the perichoretic sharing in the life of the Trinity in prayer.

Perichōrēsis en die Suid-Afrikaanse ideaal. Die voortgaande vervulling van die Suid-Afrikaanse droom van 'n 'reënboognasie' behoort op 'n geldige model gebaseer word; die Bybelse voorstelling van die 'beeld van die Drie-eenheid' kan bydra om so 'n model te ontwikkel. Dit is hier betekenisvol dat die verstaan van die Drie-eenheid dusdanig ontwikkel het dat dit die dinamiese interaksie van die Persone of perichōrēsis insluit. Indien dit as 'n model dien, weerspieël dit die onderskeid tussen samelewingsgroepe, maar ook harmonie in die samelewing, asook die volle potensiaal van elke groep. Dit behels dan die wedersydse deel hê in die gemeenskap, en moet as dinamies gesien word, sodat die land verder ontwikkel en nie op prestasies van die verlede rus nie. Vir Christene kan deel van die uitlewing hiervan bestaan in die perichoretiese deelhê deur gebed in die lewe van die Drie-eenheid.

\section{Introduction}

'Rainbow Nation' is a term believed to have been coined by Archbishop Emeritus Desmond Tutu to describe post-apartheid South Africa after its first democratic elections in 1994 (Wikipedia 2009). The term was taken up by the first president of the democratic republic as it so aptly described the dream that they both had of a nation which was united, whilst maintaining the distinctives of the various groups that comprise it. The experience of a forced separation of the groups that had been government policy for nearly half a century was repugnant; the goal was a united country respectful of the identities of its various constituents. If this could be achieved, the result, like the rainbow, would indeed be beautiful.

And, could it also be said, heavenly! It was no accident that Archbishop Tutu was appointed as the chairperson of the Truth and Reconciliation Commission, set up to investigate the abuses of the past with the express intention of healing and reconciliation. He would then have said that it was no accident that the country experienced a miracle in 1994, when the transition to a democratic government occurred without significant violence. The bloodbath that many were expecting, both within and outside of South Africa, did not occur. Whilst many of the churches had campaigned for many years to bring about a transition, they had also been praying that the result of their efforts would come about peacefully. It would surely not be unreasonable to see the hand of God both in the process leading up to 1994 and in the event itself. The appointment of the archbishop was recognition of a commonly held belief that God had influenced the process.

Although the peaceful transition, and the subsequent peaceful interrelating of the groups, remains a surprise to many, it really should not have been, at least not in a Christian context. The separation and mutual antagonism in the ancient world between Jew and Gentile was far more extreme, and yet this had been transcended in Christ (Eph 2:11f.).

But have the churches now lost interest? Is the achievement of the transition now viewed as enough? If the development of the young democracy is also in keeping with the will of God, then Christians have a duty to work for it, to pray for it, and to expect that God will indeed respond to those prayers. 


\section{The goal}

I want to suggest that God is concerned with human society, that the preservation and development of South Africa is in keeping with his will, and that he wants to bring about an ideal society. This is the essential reason for the involvement of Christians, and also why so many resisted the policies of the previous regime. Despite many attempts to argue that the system of apartheid was consistent with the Bible, it was increasingly condemned as wrong, and indeed sinful. The Kairos document (1985) is a well-known reflection of this sadly, being increasingly forgotten. The system of apartheid then had to be replaced by one which could be described as reflecting the will of God. The question is: What does this mean? What is needed is a role model.

Incidentally, perhaps part of the problem with the apartheid structures was that apartheid's architects were well aware of racism elsewhere - the southern states of America being an obvious example. They then sought to perfect what they observed had not been carried through logically. The challenge to modern South Africa, then, is to produce a society that can be an example to other countries. Certainly after 1994, South Africa acquired a vast amount of moral capital, capital that is now, especially with the recent spates of xenophobia, in danger of dissipating.

Surely the ideal society is one which reflects the nature of God himself: 'In Jesus Christ, he creates a community of faith corresponding to his nature; in turn the civil community should reflect this in its life' (Thompson 1994:109, citing Barth). The Genesis narrative recounts that humanity was created in imago Dei [image of God] (Gn 1:27), and that this was 'good'. Humanity's goal should be to reflect the nature of its creator as closely as possible.

Indeed, although the image is commonly understood as referring to the individual, the Genesis account is of the creation of the first community, as Barth (1958:197-198) has observed. Others, perhaps notably Wheeler Robinson (1926:8) with his understanding of 'corporate personality', have pointed out that the Old Testament focuses on the community. Likewise, Jesus came to build a community, the Church, which is his body (1 Chr 12:27).

This means that the Church, and ideally society as a whole, should reflect the nature of the Trinity. The goal is not just to be in imago Dei [image of God], but to be in imago Trinitatis [image of the Trinity]. Many, such as Volf (1998), see the Church as reflecting the Trinity. Boff (1988:11) particularly takes up this point, saying that the Trinity can serve as a model for a just egalitarian organisation. Famerée (2007:58) believes that the Church proceeds from the inner life of the Trinity, and manifests it in the world. In this case, 'the Trinity is our social program' (Moltmann, citing, amongst others, Fedorov, in Thompson 1994:106).

And here the rainbow is indeed an appropriate picture. Perhaps the delightful picture that Tutu used can be pressed a little more, for the rainbow comes from the interaction of three primary colours. Ordinary sunlight does appear as an undifferentiated unity, which is how the nation should appear from the outside. Although sunlight is composed of completely identifiable and separable elements, these manifest themselves together. One is reminded of the Trinitarian dictum, opera Trinitatis ad extra indivisa sunt [external actions of the Trinity are undivided]. This does not mean that the actions of the Persons cannot be distinguished; it means that all the Persons are involved in every external action and that in these there is harmony.

Now, it is always dangerous to propose an illustration; Barth is well known for resisting the use of things to illustrate spiritual truth. It cannot be that humanity can fully reflect either the nature of God or the relationships in the Godhead; indeed, it is precisely for this reason that the second Person limited himself in kenōsis [self-limitation]. Nobody can see God and live. And certainly it is dangerous to press an illustration further than is reasonable. It could well be observed that the rainbow is actually due to the separation of the colours that together make up ordinary sunlight, a point probably not really intended.

Even when the principle that using the Trinity as a paradigm for the ideal human society is accepted, it must still be recognised as a little precarious, for it may well lead to unwanted implications. In particular, the way in which the Trinity is usually presented cannot serve as a model for what is desired in South Africa. If the Trinity is seen as the Father begetting the Son, and then the Spirit coming from him, whether with or through the Son, this immediately demands the subordination of the second and then the third Person to the first. It can justify patriarchy, monarchism, domination (Boff 1988:14). The Trinity is often formulated in a sense that enshrines subordination; the classic case of this was in Arianism. But despite the condemnation of this as a heresy, the affirmation of processions means that the implication remains, and militates against seeing the Trinity as a paradigm for the ideal society. Is this subordination really what is intended? Was this not the agony of the situation under apartheid?

Indeed it is, if those relationships are seen as inherent. But in fact this is not the case: Arius, in the 4th century, made exactly the mistake of reading the subordination of the incarnation and earthly presence of the Spirit back into the essential nature of the Godhead (LaCugna 1993:34). His condemnation was, and is, absolutely correct. As Athanasius and so many others have insisted to this day, the Persons are absolutely equal, all are fully God (Torrance 1996:143). What is perhaps significant is that the reason for Athanasius's determination was the perception that if the Persons are not all equal, all fully divine, then there is no salvation (Torrance 1996:144). The same is true for South Africa; if there is not full equality, then ultimately there will be no salvation.

\section{Perichōrēsis}

The problem that the 4th-century dispute highlighted is that if there was full equality, where was the distinction between the Persons? Whilst the affirmation of the Nicene Creed was 
that the three Persons are homoousios [of the same being], so absolutely equal, the implication of this was that they could not be distinct Persons (Torrance 1996:171). Then if the Persons are in fact distinct, they must be different in at least some respect and, if different, they could not be absolutely equal (Torrance 1996:115). When Athanasius insisted on the term, homoousios, that had been agreed to by the Council of Nicea, albeit under a measure of political pressure, he was accused of Sabellianism, the idea that there was only one Person of God but a God who manifested in various ways, as Father, Son or Holy Spirit (LaCugna 1993:47). This however did not reflect the biblical material, which clearly indicates that there are real distinctions between the Persons, such as at the baptism of Jesus ( $\operatorname{~k~3:22),~where~he~was~clearly~}$ not the same person as either the voice from heaven or the descending dove.

This dispute raged for several decades until it was realised how it was possible for the Persons to be both distinct and absolutely equal, in the formula known as perichōressis (Torrance 1996:138). If it is understood that deity is communicated from one to the other, then they can be absolutely equal, with no subordination and 'without loss of relational distinctiveness' (John of Damascus, cited by Lampe 1978:120), so that difference is maintained. The first application of the term to the Trinity was by an unknown writer in a work attributed to Cyril (Torrance 1996:170), but it was the Cappadocian Fathers in the fourth century who realised that the doctrine of perichōresis provided the solution to the problem that had vexed the Church since the emergence of Arius (LaCugna 1993:270). Referring to Kelly, Bray (1993:162) can treat the doctrine of co-inherence as an 'undoubted advance in thinking'.

Each Person of the Trinity is distinct from the others, but in order for the three Persons to be absolutely equal, they interpenetrate. Interestingly, Long (2006) cites Ian Bradley in his The Celtic Way, who says: 'The intertwining ribbons of the Celtic knot represent in simple and graphic terms the doctrine of perichoresis - the mutual interpenetration of Father, Son and Holy Spirit' (Long 2006). Jesus could say that he is in the Father and the Father in him (Jn 14:11). Each Person envelops and is enveloped by the others (chōreō [contain]) (Torrance 1996:170). Volf (1998:209) explains this as co-inherence without coalescence or commixture. Otto (2001:368) says that the use of the prefix peri-probably indicates the completeness of the mutual interpenetration. The relational attributes pertaining to specific Persons, such as Fatherhood, are of course not communicated (Crisp 2005:138). Although Athanasius had understood that the concept of homoousios involved both real distinction and real co-inherence (Torrance 1996:169), this was not really appreciated fully at the time.

More than the equality of the Persons, it is this interaction that gives unity between them, not the identity of substance (Volf 1998:210). Moreover, it is in the very relationships that the Persons have their full identity. Gunton then says that the reality of the Persons is only in their relationship to one another (Chia 2007:457). Thus the Son is generated or begotten by the Father (Jn 1:14); the very word 'Father' indicates the presence of the Father in the being of the Son. Each Person is only such in relation to the other two (Torrance 1996:172). The Son is only the Son insofar as he is indwelt by Father and Spirit (Volf 1998:209).

The interaction of perichōrēsis enables the full three-in-oneness of the Trinity (Barth 1975:370). Moltmann (1981:175) says of the Persons of the Trinity that 'in the perichoresis, the very thing that divides them becomes that which binds them together'. Legitimate variety will contribute to unity (Famerée 2007:58). Having noted that the Father is associated with the 'ineffable abyss', the Son with time-space objectivity and the Spirit with inner- and interpersonal subjectivity, Peters (1993:147) feels that 'the concept of perichoresis holds together the dimensions of absoluteness and relatedness in the single divine life'. Crisp (2005:131) uses the illustration of the oxygen and haemoglobin in oxygenated red blood cells in the human body, which are chemically distinct, but fused together to make oxyhaemoglobin in order to deliver oxygen to the body efficiently; this is a significant comparison, as blood is the centre of human life.

Just as it is this perichoretic interrelationship that is fundamental to the idea of a human being, Erickson (1995:233) - applying it to the life of a body, an idea that underlies Paul's picture in 1 Corinthians 12:4f. - this can be extended to society as a whole; the essence of civilisation is the mutual interaction and support of the people that it comprises. Just as the Trinity is not a simple fellowship of Persons, which would be tritheism (Thompson 1994:108), so society is more than a collection of people inhabiting a particular area. Famerée (2007:64) says that each local church is a portion, not a part, of the whole; it reflects the Trinity, not tritheism, and all are equal (2007:60). In addition: 'The Trinity forms the social paradigm since it is a mutually loving, interacting, sustaining society' (Thompson 1994:106). Thus the idea of perichōrēsis forms a model for the Church and so for human society:

...this doctrine of co-inherence is perhaps the most important single teaching of the Bible in an age which finds it hard to reconcile individual freedom and dignity with corporate commitment and responsibility. (Bray 1993:242)

It is also noteworthy that Volf (1998:209) sees a similar mutuality in prophetic speech, insofar as many see that the Church has a prophetic function to society, and perhaps especially in South Africa.

Seeing the Trinity as fundamentally perichoretic indicates that the ideal society does not reflect ongoing dependence, but interdependence; it is this that gives unity. Nevertheless there will be temporary dependence as a means of achieving this, reflecting the fact that in the 'economic Trinity', which manifests as the means of salvation, the Son and the Spirit are dependent on the Father in generation and procession; this is, however, not a permanent state. The imperative is then the affirmation of full perichoretic relationships that safeguard the essential equality of the Persons in the Trinity, and in its imitation, a healthy society.

Buxton (n.d.:1) refers to the understanding of such as Gunton, that even the nature of the universe, as created by God, 
reflects this perichōrēsis: 'God's own ecstatic perichoretic life finds expression in the creation that he has brought into being' (Buxton n.d.:2). Gunton therefore advocates a perspective on the world that is ultimately perichoretic in that everything in creation contributes in some way to the being of everything else (Buxton n.d.:9). This, then, gives 'meaningful expression to the dynamical order of the universe as a coherent, evolving pattern in which all things participate' (Torrance, in Buxton n.d.:11). It follows that 'all of God's acts have behind them the full weight of the Trinity whilst simultaneously each person of the Trinity retains his own distinct identity' (Buxton n.d.:6, citing Torrance). The trinitarian nature of creation then reflects in the Church (Chia 2007:454).

The term perichōron appears in Septuagint (Greek translation of the Old Testament) to refer to those who 'dwell around' a town (Gn 13:10), and one reference in the Gospel of Matthew (14:35) has that same meaning. When translated into Latin, two renderings of the term emerged, circuminsessio, to sit around, the understanding preferred by Aquinas; and circumincessio, to move around, preferred by Bonaventure (LaCugna 1993:272). Torrance (1996:171) adopts the latter, feeling that perichōrēsis is essentially dynamic. It is this latter sense that is especially applicable to society, for people do not only dwell together in a static sense, but also interact. Moreover, as Otto (1992:510) states: 'Humanity by its very nature is social and is meant to reflect the community of relations (perichoresis) within the triune God'. On the other hand, the idea of dancing around can overstress the individuals, so it loses real interpenetration (Tan 2004:291). Both aspects are then essential: Society is neither merely a collection of individuals nor just an undifferentiated body.

Thus, insofar as they reflect the perichōrēsis of the Trinity, the various elements of South African society find their full identity in their interaction with the others. Full humanity comes only in the context of shared relationships (Otto 2001:379). Dialogue is basic to our existence as the Trinity is dialogue (Tan 2004:287). The very diversity is then mutually enriching. At the same time, there can be both inherent unity and equality in the country. What must be said is that perichōrēsis was, and still is, seen not just as a form of words, or a formula craftily contrived to reconcile the irreconcilable, but reflected a reality. Perhaps if human society had been what it should have been, and reflected the nature of the Trinity more closely, this realisation might have come sooner. But now that the realisation had dawned, there came also the challenge to conform to it.

\section{Kenōsis}

The essence of perichōrēsis is the giving of each Person to the others; indeed, giving may be seen as fundamental to the nature of God. This is then seen in God's action outside of himself, both in the act of creation and especially in ongoing action in the created world. This would suggest that the incursion of God into the world is necessarily kenotic, a concept which complements perichōrēsis (Buxton n.d.:8). In fact, the term perichōrēsis was first applied theologically in respect of God's primary intervention into the world, in the incarnation, where it was applied to the interplay of the divine and human in Christ (LaCugna 1993:272). Here the hypostatic union demands an understanding of perichōrēsis, here called the communicatio idiomatum [communication of properties] (Crisp 2005:125). Crisp (2005:130), however, cautions that these are not quite the same, because in the case of the latter the relation is asymmetrical, as the attributes of humanity do not enter the divine.

In the giving that is implicit in perichōrēsis, 'each of the persons surrenders its own independence on behalf of the divine unity. The Trinity is a model of reciprocal self-denial' (Peters 1993:137). Pannenberg (in Peters 1993:224, fn.120) thanks Hegel for this insight, calling it the most profound clarification of the inner trinitarian perichoresis to appear in the history of Christian thought'. That relationality, it must be remembered, is in fact constituted by self-giving. Each divine person is who it is in and through the giving of itself to the other (Peters 1993:137). Mark McIntosh (in Pinti 2006:505) claims that this 'going out' of the divine Persons involves creation as a whole: 'In a sense we could say that the whole cosmos and its responsivity to God are embraced within the infinitely fecund giving of the Divine Persons to each other. (p. 505)'.

What God did was to give. What Christ did was to give. And the heart of the perichoretic reality is the continual giving of the Persons to each other. And this is a very Christian value. It is often pointed out that the use of the word agape, 'love', was rare before the coming of the gospel. The African ideal of ubuntu [human kindness] can find a deeper basis and fuller expression in Christ. Is it possible that progress will be made in achieving a better South Africa without that same attitude of ongoing giving? The establishment of a perichoretic society involves reflecting the means that the Trinity adopted for salvation, that of the self-giving of kenōsis. Certainly relating to others involves self-giving (Volf 1998:211). It is significant that the early Church, in their realisation of salvation, quickly adopted the relationships of koinonia [communion or fellowship]: as Boff (1988:6) points out, this is implied in perichōrēsis.

In giving, there must be a measure of self-emptying; this is a concept particularly highlighted in the Philippian 'hymn' of Philippians 2:5f. Whilst the idea of kenōsis has attracted a lot of criticism, this is blunted when it is appreciated that the emptying is not a negation of attributes, but a self-limitation. Thus Christ, and, incidentally, also the other two Persons, whereas they self-limit in their interaction with the world, so in their immanent action they remain absolutely divine in themselves, so in their transcendence.

In this case, the interaction of people in society, if it is to reflect the Trinity, is necessarily one of giving, of selflimitation for the sake of others. Yet it will be found that this action is not one that results in loss, but in fact enriches. In his kenōsis, Christ benefited in the experience of becoming human (Phlp 2:10). In South African society, the experience of self-giving in the perichoretic relationship will be found not to cause loss, but be mutually beneficial. 
It might just be added here that the perichoretic interrelationship of the Trinity and its kenotic expression in the world are without compulsion. God self-limited in creation to give free-will to humanity, and in his ongoing dealings with the world the same is true. God may urge, but does not force (some have referred to the Holy Spirit as a 'gentleman'!). Thus the ideal for human society should not be imposed by legal compulsion (as was the case, classically, of course, with apartheid), but given though example. Here, whereas the model is the Trinity, it is best perceived in society as a whole through the Church. The tragedy is that so very often the Church fails to live up to the model that it has been given.

\section{The process}

Even though 1994 witnessed a tremendous accomplishment, despite democracy at last being achieved, this was not the end of the story. The transition to democracy must be seen as part of a process, which again reflects the nature of the Trinity. The Trinity is not three Persons in a static relationship with one another, they are in a continual dynamic interchange. The very essence of the idea of perichōressis is that it is a process. Torrance (1996:171) points out that perichōrēsis is essentially dynamic. So if the Trinity is a paradigm for the perfect society, it should not be seen as ever being fully achieved.

In fact, one of the problems that the early Church inherited from its milieu is the view that if God is perfect, he must be 'perfectly' unchangeable. One of the results of this idea was the notion that God cannot suffer; it has been a modern realisation, especially since the sufferings of the Second World War, that God can indeed suffer, and participates in our own suffering. Contrary to the old belief that what Jesus endured could not be real, an idea known as 'docetism', the portrayal of the Bible is realistic and, indeed, the sufferings of Christ were essential to our salvation. Moreover, the Father also suffered, not least in that he gave up his Son for the sake of the world.

It is one of the tragedies of the modern South Africa that many people despair of achieving a society that is significantly better. In a sense this must definitely be a Christian attitude, one which has an appreciation of the enormity of the sinfulness that underlies prejudice and hatred. Yet surely a Christian must perceive that God's power has been effective in countless peoples' lives and situations, not least in 1994 and in the ancient world.

But is there now a feeling that after the changes of 1994 nothing more needs to be done? Are we echoing the words of Jesus on the cross, 'it is finished' (Jn 19:30)?

Admittedly, since the start of the Church, the cross and example of Christ have inspired the sacrifice of many for the sake of others. And this includes many who sacrificed themselves for the sake of others in South Africa and a better society. Surely the achieving of democracy would not have occurred had it not been for so many who suffered to bring it about. But for most there is just acceptance of what has been done, even appreciation for it, but little realisation that more needs to happen.

It is here that the Trinitarian picture can again make a contribution. A verse beloved of Christians is John 3:16: 'For God so loved the world that he gave his only begotten Son ....' Whilst this must primarily refer to the event of the incarnation, this should not imply that that phenomenon ended God's involvement. This does not reflect the inter-Trinitarian relationship. Arius had made the mistake of understanding the begetting of the Son as an event, albeit before time, which immediately implied for him the inherent subordination of the Son. It was the realisation of the genius of Origen that the relationship between the Persons cannot be seen as an event, but as an eternal process (Torrance 1996:208).

But there is a modern heresy, which can perhaps be seen as even more devastating than the ancient one of Arius, but which comprises an equally destructive notion: it is that salvation is also just an event and that once it has happened, the story is complete. And it is the same 'heresy' that is so prevalent in South Africa today, the belief that democracy has been achieved, utopia has come, nothing more needs to be done.

How many people look back on their conversion, or on their baptism, and, quite rightly, rejoice that their sins are indeed forgiven, but think that there is no need to do anything else? Indeed, how many rejoice with Paul that salvation is entirely of grace, a gift of God, and in no sense dependent upon human action? Salvation is sola gratia, entirely a gift ( $\mathrm{Rm}$ 3:24, Eph 2:8). But that same Paul had to cry out in horror when some understood this to mean that they did not need to do anything further, and James likewise insisted that faith leads to works (Jm 2:14). This was Bonhoeffer's problem: the lack of perception by many of his fellow Lutherans that obedience was necessary; what he called 'cheap grace'. Rather, for Paul, grace is free, but it costs everything (Hinson 1988:45-46)!

Witness the experience of the Augustinian monk, Martin Luther - from whose realisation that God had saved him by faith had come the Protestant understanding of salvation, fundamentally by the free gift of God, by grace alone. This was, of course, not novel to him, but it reflects the understanding of Paul, expressed especially in the epistles to the Romans and the Galatians, and notably, emphasised by Augustine.

In his early life Luther had struggled with the awareness of sin in his life; whilst believing in his salvation, he was painfully aware of his unworthiness. For Luther, the dilemma was resolved in the realisation that when he was justified, far from it being from holiness of life, and even far from being made holy, he was rather declared to be righteous, and in that sense becomes holy. Justification is the removal of the guilt of sin; righteousness is 'imputed' to the believer. He realised that justification is a gift, an act of grace, so not at all dependent upon the acts or works of the sinner. In justification, a person is declared, not made, holy. Justification is then a declaration, in a legal or forensic sense, that the person is no longer liable 
to any penalty. No charge can be brought against God's elect ( $\mathrm{Rm}$ 8:33). This is the normal biblical understanding of the Hebrew $s d k$ and the Greek dikaioo [to declare] (Toon 1983:14, 120).

But understood in this way, it can well be thought that receiving the gift of salvation in no way actually affects a person so that he or she is better off in this life. In Protestant theology, a distinction is usually made between two aspects of salvation, the forgiveness of sins and an improvement in life. The believer, at least initially, is not in the least better in a moral sense. Understood in this way, it follows that the act of salvation in justification does not necessarily affect the present. Speaking of Luther, Wesley said that none wrote more aptly of justification by faith, none were more ignorant of sanctification (Edwards 1965:50). Indeed, it has been a common trend in Christianity that salvation has tended to be understood only in terms of escape from the threat of hell, the result of sins, to an eternal home in heaven. The emphasis has been almost entirely eschatological.

These factors can make salvation effectively irrelevant in the present life. However, Wesley, amongst others, insisted that the 'vulgar notion' of salvation as simply a release from hell or going to heaven is quite inadequate (Dieter 1987:27). Indeed, because of the forensic emphasis, Barth could rightly complain that Europe was full of baptised pagans, people being confident of their heavenly salvation, but seeing no necessity for this to affect them in this life. So often only forgiveness by the cross is preached, whilst there is a need of a deeper work (Hegre 1960:39). The glory of justification can be succeeded by the horror of anomianism (literally lawlessness) or, even worse, antinomianism (acting contrary to the law) (Marshall 1981:73). (The logic to the latter is that if God is so happy to forgive sin, let us make him even happier by sinning more!) It is understandable that a stress on salvation by grace can immediately be felt to permit, or even to encourage, a freedom to behave exactly as desired. If justification is just forensic, so that it does not come with a real change in a person, it is even dangerous, as it leads to antinomianism and so sin. This was Wesley's early view (Toon 1983:103). Paul seems to have been accused of this, and has to vehemently respond to these in Romans 6 and Romans 7: 'Are we to continue in sin that grace may abound?' (Rm 6:1). Furthermore: 'Are we to sin because we are not under law but under grace?' (Rm 6:15). To both of these accusations comes the exclamation, 'By no means!' (Rm 6:1, 15). Not surprisingly, Luther was also accused of the same error; in his case perhaps he encouraged it by his rejection of the book of James.

If salvation is restricted to a forensic declaration of forgiveness, it then loses the fact that it is a Trinitarian action. It has often been noted that an overemphasis on a penal substitutionary theory of the atonement divides the Father and the Son. Then if forgiveness is all that is necessary, the Spirit becomes redundant. Christianity becomes Christomonism and the Trinity becomes irrelevant. Western Christianity has indeed often reflected these losses.
However, despite his stress on grace through faith, Luther had in fact insisted that faith is more than just assent, but includes the will; it then becomes life-changing, so is more than just an event, but includes a continuing process (Toon 1983:58). Whilst justification is a completed act, there are degrees of sanctification (Ryle [1879] 1979:105). There is still a paradox, though; Luther famously asserted that a Christian is simul iustus et peccator [at the same time justified and a sinner]. This does not mean that perfection, either of the individual or of society, will be achieved. Indeed, whilst God may be seen as perfect, people never are. But this must not be seen as a disincentive to making as much progress as possible towards that goal.

Sin is not eliminated, only forgiven (Berkouwer 1952:75); it then needs removal. Calvin (in Hinson 1988:92 urged people 'to embrace Christ, not only into righteousness, but also unto sanctification'); it is worth noting the choice of prepositions, contrasting 'into' and 'unto'. Even if justification is understood in a forensic sense, it has immediate ethical implications - the Hebrew term for righteousness, $s d q$, embraces both aspects (Toon 1983:35). The Old Testament prophets could insist that covenant relationship with God was sterile unless it resulted in work; Micah 6:8 is a clear example (Toon 1983:15).

I have elsewhere suggested (Williams 2009:267) that a full understanding of the atonement has three essential aspects: the forgiveness of sins, essentially forensic; the giving of eternal life by union with Christ; and a repentance, which commences a process of sanctification. The traditional theories of the atonement tend to adopt just one aspect, and are each then inadequate without the others. The importance of this lies in the fact that if justification is simply forensic, there may well be forgiveness, but it is not really salvation; this depends on a union with Christ, demanding repentance. This repentance is not just sorrow, but includes a turning to God (Calvin [1559] 1989:524), and then inevitably ushers in a changing life. Expounding on 1 Peter 4:1, Stibbs (1959:148) writes that the union with Christ produces a 'new and right attitude of mind as being fundamental to that radical change of behaviour which ought to express itself in the lives of all who belong to Christ' (see also Eph 1:4).

An example might help at this point. If a garment is dirty, it cannot really be worn until it is cleaned. Now the usual way of doing this is by washing. This will remove the dirt, but the garment still cannot really be worn whilst it is still wet. It has to be dried off before it can do the job for which it is intended. Usually this is done by hanging it up in the sun and wind remember the fire and wind of the Day of Pentecost?

The essential point is that even though there was an event of liberation, whether through the cross for the individual or through the establishment of a democratic government, this must be seen as the start of an ongoing process towards real improvement. The goal is a reflection of the perichoretic inter-relation of the Trinity. And with that goal, God's help is assured, just as the Spirit was sent to enable the ongoing progress of the individuals and the Church. 


\section{The means}

Is the goal of a perichoretic society in South Africa just a dream, an impracticable, even unreasonable one? After all, perichōrēsis is strictly applicable only to the immanent Trinity, as people only relate externally (Volf 1998:211); however, it is reflected to a degree in human society. The Christian is 'in Christ' and 'in the Spirit', which although it does not mean being present in them in the full perichoretic sense, in their persons (Volf 1998:211), does result in openness to the other, so that in this way people can reflect the unity of God in their own unity (Jn 17:23). The 'unity of the Church is grounded in the interiority of the Spirit' (Volf 1998:213). The implication is that perichoretic unity in a full sense depends on a full Christian commitment; however, this is said in the context that the majority of the South African population does claim to be Christian. The challenge is to manifest the full implications of this.

The reflection of perichōrēsis in the indwelling of believers by the Father is then the result of their belief; John's soteriology is necessarily perichoretic (Crump 2006:411). Then, just as the indwelling of the Father was the source of the power of the Son (Crump 2006:402), so it enables that of believers. We change by the impartation of the divine life. From another New Testament author, the minds of believers are transformed (Rm 12:2), which enabled the Christian lifestyle that is the burden of the last part of that epistle.

Finally, there is one thing that all should do, one commanded in the Scriptures (1 Tm 2:2). Whilst the focus must fall on action, and cooperative action in the spirit of perichōrēsis, this is not the end of the matter. The archbishop would concur that much was achieved by the hand of God in response to prayer and, indeed, Christians have a responsibility to pray for their government. How many Christians just complain about taking even this basic step? But this is right, and also in keeping with the ideal of perichōrēsis.

It has been suggested that prayer becomes a participation in the life of the Godhead itself, a relationship itself enabled by the Spirit (Taylor 1972:226). Prayer is then participation in God (Leech 1980:8); it is then 'something in which we join' (Wyon 1962:33). In addition: 'Our prayer is only true prayer to the degree in which it is one with His' (Father Andrew, in Wyon 1962:32). As adopted children, what we are doing is sharing in the praying of Jesus (Taylor 1972:226); we participate in perichōrēsis; we have access to God in his access (Wyon 1962:40).

Nédoncelle (1962:viii) cites the assessments of Maistre, namely, that the value of a civilisation rests on the quality of its prayer, and of Toynbee, that prayer is the only foundation for human solidarity.

\section{Acknowledgements Competing interests}

The author declares that he has no financial or personal relationship(s) that may have inappropriately influenced him in writing this article.

\section{References}

Barth, K., 1958, Church dogmatics, vol. 3(1): The doctrine of Creation, T\&T Clark, Edinburgh. Barth, K., 1975, Church dogmatics, vol. 1(1): The doctrine of the Word of God, 2nd edn., T\&T Clark, Edinburgh.

Berkouwer, G.C., 1952, Faith and sanctification, William B. Eerdmans Publishing Company, Grand Rapids.

Boff, L., 1988, Trinity and society, Orbis, Maryknoll.

Bray, G.L., 1993, The doctrine of God, InterVarsity Press, Leicester.

Buxton, G. n.d., 'On the trinitarian doctrine of perichoresis', in Staff papers, viewed 01 June 2010, from http://www.taboradelaide.com/

Calvin, J., [1559] 1989, Institutes of the Christian Religion, vol. 1, William B. Eerdmans Publishing Company, Grand Rapids.

Chia, R., 2007, 'Trinity and ontology: Colin Gunton's ecclesiology', Internationa Journal of Systematic Theology 9(4), 452-468. http://dx.doi.org/10.1111/j.1468 2400.2007.00274.x

Crisp, O.D., 2005, 'Problems with perichoresis', Tyndale Bulletin 56(1), 119-140.

Crump, D. 2006, 'Re-examining the Johannine Trinity: Perichoresis or deification?' Scottish Journal of Theology 59(4), 395-412. http://dx.doi.org/10.1017/S00369 30606002547

Dieter, M.E., 1987, 'The Wesleyan perspective', in M.E. Dieter, A.A. Hoekema, S.M. Horton, J. Robertson McQuilkin, J.F. Walvoord \& S.N. Gundry (eds.), Five Views on Sanctification, pp. 9-46, Zondervan, Grand Rapids.

Edwards, M., 1965, 'John Wesley', in R.E. Davies \& E.G. Rupp (eds.), A history of the Methodist Church in Great Britain, pp. 35-79, Epworth Press, London

Erickson, M.J., 1995, God in Three Persons: A contemporary interpretation of the Trinity, Baker Publishing Group, Grand Rapids.

Famerée, J., 2007, 'Local churches, universal Church and other churches in Lumen Gentium', Ecclesiology 4(1), 52-67. http://dx.doi.org/10.1177/1744136607080896

Hegre, T.A., 1960, The Cross and sanctification, Bethany House Publishers, Bloomington.

Hinson, E.G., 1988, 'A contemplative response', in D.L. Alexander (ed.), Christian spirituality: Five views of sanctification, pp. 44-46, 91-93, 129-131, 168-170, InterVarsity Press, Downers Grove.

Kairos 1985, The Kairos Document: Challenge to the Church: A theological comment on the political crisis in South Africa, The Kairos Theologians, Braamfontein.

LaCugna, C.M., 1993, God for us: The Trinity and Christian life, HarperCollins Publishers LLC, San Francisco.

Lampe, G.W.H., 1978, 'Christian theology in the Patristic period', in H. Cunliffe-Jones (ed.), A history of Christian doctrine, pp. 21-180, T\&T Clark, Edinburgh.

Leech, K., 1980, True prayer: An introduction to Christian spirituality, Sheldon Press, London.

Long, B., 2006, 'Perichoresis (Circumincession)', in drbilllong.com, viewed 01 June 2010, from http://www.drbilllong.com/Prefixes/Perichoresis.html

Marshall, W., 1981, Gospel mystery of sanctification, Evangelical Press, Darlington.

Moltmann, J., 1981, The Trinity and the Kingdom of God: The doctrine of God, SCM Press, London.

Nédoncelle, M., 1962, The nature and use of prayer, Burns \& Oates Publishers, London.

Otto, R.E., 1992, 'The imago Dei as familitas', Journal of the Evangelical Theological Society 35(4), 503-513. http://dx.doi.org/10.1017/\$0036930600051656

Otto, R.E., 2001, 'The use and abuse of perichoresis in recent theology', Scottish Journal of Theology 54(3), 366-384.

Peters, T., 1993, God as Trinity: Relationality and temporality in divine life, Westminster John Knox Press, Louisville.

Pinti, D., 2006, 'Julian's audacious reticence: Perichoresis and the Showings', Anglican Theological Review 88(4), 499-517.

Ryle, J.C., [1879] 1979, Holiness: Its nature, hindrances, difficulties and roots, Evangelical Press, Darlington.

Stibbs, A.M., 1959, The First Epistle General of Peter: A commentary, Tyndale House Publishers, London.

Tan, S-K., 2004, 'A trinitarian ontology of missions', International Review of Mission 94(369), 279-295. http://dx.doi.org/10.1111/j.1758-6631.2004.tb00459.x

Taylor, J.V., 1972, The go-between God: The Holy Spirit and the Christian mission, SCM Press, London.

Thompson, J., 1994, Modern Trinitarian perspectives, Oxford University Press, New York. Toon, P., 1983, Justification and sanctification, Marshall, Morgan \& Scott Publications, Ltd., London.

Torrance, T.F., 1996, The Christian doctrine of God, One Being Three Persons, T\&T Clark, Edinburgh.

Volf, M., 1998, After our likeness: The Church as the image of the Trinity, William B. Eerdmans Publishing Company, Grand Rapids.

Wheeler Robinson, H., 1926, The Christian view of man, 3rd edn., T\&T Clark, Edinburgh.

Wikipedia, 2009, Rainbow nation, viewed 04 June 2010, http://en.wikipedia.org/wiki/ Rainbow_Nation

Williams, D.T., 2009, Kenōsis of God: The self-limitation of God - Father, Son, and Holy Spirit, iUniverse, Bloomington.

Wyon, O., 1962, Prayer, HarperCollins Publishers LLC, London. 